\title{
Bacterial Leaf Scorch in the District of Columbia: Distribution, Host Range, and Presence of Xylella fastidiosa Among Urban Trees
}

Jordan L. Harris, Department of Plant Science and Landscape Architecture, University of Maryland, College Park 20742; Patrick L. Di Bello, Cell and Molecular Biology Program, Department of Plant Pathology, University of Arkansas, Fayetteville 72701; Monica Lear, District Department of Transportation, Urban Forestry Administration, Washington, DC 20003; and Yilmaz Balci, Department of Plant Science and Landscape Architecture, University of Maryland

\begin{abstract}
Harris, J. L., Di Bello, P. L., Lear, M., and Balci, Y. 2014. Bacterial leaf scorch in the District of Columbia: Distribution, host range, and presence of Xylella fastidiosa among urban trees. Plant Dis. 98:1611-1618.

A survey of urban trees affected by bacterial leaf scorch (BLS) caused by Xylella fastidiosa was conducted in the District of Columbia during 2011 and 2012. Over 20 species of urban trees were evaluated at 95 sites. Symptomatic and asymptomatic foliage from trees with BLS symptoms and foliage from neighboring asymptomatic trees were sampled. An $X$. fastidiosa-specific enzyme-linked immunosorbent assay (ELISA) and a polymerase chain reaction assay were used to detect and identify the strains from environmental samples. Symptomatic trees testing ELISA-positive for $X$. fastidiosa occurred most frequently with Quercus palustris, Q. rubra, Ulmus americana,

identified on eight other symptomatic and five asymptomatic tree species. On infected trees, the bacterium was also detected on the asymptomatic portion of seven tree species. All strains were identified as the $X$. fastidiosa subsp. multiplex genotype ALSII except on Morus alba, where the genotype ALSI and the subsp. sandyi were detected. The occurrence of crown dieback was found significantly associated with $X$. fastidiosa-infection on $Q$. palustris, Q. rubra, U. americana, and $P$. occidentalis. Because this pathogen continues to perpetuate uncontrolled in urban environments, there is a pressing need to identify long-term management strategies that abate disease.
\end{abstract} and Platanus occidentalis. The bacterium was also less frequently
Xylella fastidiosa (49) is the causal agent of bacterial leaf scorch (BLS), a chronic leaf-scorching disease of landscape woody ornamentals (42). Leaf scorch symptoms first develop on an isolated branch within the crown of a tree and an annual progression of leaf scorch ensues until the entire crown is affected (42). X. fastidiosa can cause decline of mature oak (Quercus spp.), elm (Ulmus spp.), sycamore (Platanus spp.), maple (Acer spp.), and red mulberry (Morus rubra) $(17,28,46)$. Numerous surveys have established the incidence of BLS within multiple jurisdictions throughout the eastern-Atlantic region $(14,15,32,45)$. In several Maryland and New Jersey municipalities, the cost for maintaining and removing BLSaffected oak trees has been estimated to exceed one million dollars over a period of 5 to 10 years, an economic burden that well exceeds most normal tree budget allocations (10).

Previous surveys of BLS provide evidence of a wellestablished occurrence of BLS among urban trees in the District of Columbia $(17,32,45,50)$. The economic implications associated with the maintenance and removal of BLS-infected trees within the District have forced regional researchers and arborists to devise management strategies in response to this chronic disease. Palliative responses such as oxytetracycline injections and plant growth regulators such as paclobutrazol are not curative and only help alleviate the deleterious symptoms of this disease $(8,11,27)$. Pruning to remove infected branches of a tree has not yet been proven as an effective method for mitigating the occurrence or severity of BLS, and little is known about the

Corresponding author: Y. Balci, E-mail: ybalci@umd.edu

Accepted for publication 14 May 2014.

http://dx.doi.org/10.1094/PDIS-02-14-0158-SR

(c) 2014 The American Phytopathological Society prevalence of this pathogen beyond the visibly symptomatic portions of host trees.

Identification of various $X$. fastidiosa subspecies among urban trees can assist with understanding disease epidemiology and control. Currently, there are five subspecies of X. fastidiosa that have been described, including subsp. fastidiosa, known for causing Pierce's disease of grapevine (Vitis spp.); subsp. multiplex, known for causing leaf scorching diseases of numerous landscape ornamentals; subsp. pauca; known for causing citrus variegated chlorosis on citrus; subsp. sandyi, known for causing leaf scorch of oleander (Nerium oleander); and a newly described subsp. tashke, known for leaf scorch of chitalpa (Chitalpa tashkentensis) (38-40).

In order to determine the distribution, host range, and subspecies identity of $X$. fastidiosa in the District, a survey of symptomatic and asymptomatic trees was conducted. Our specific objectives were to outline latent infection among urban trees and identify genetic variability of $X$. fastidiosa within infected plant tissue of different tree species. The host range of BLS among various urban trees in the District was determined with enzyme-linked immunosorbent assay (ELISA). A polymerase chain reaction (PCR) assay was used to determine the subspecies of $X$. fastidiosa infecting multiple species of urban trees in the District. Results from this investigation will provide baseline information for developing management options in response to BLS in urban municipalities.

\section{Materials and Methods}

Sample collection. During the first year of the study (30 August to 26 October 2011), 169 leaf-scorched trees within the District were identified using Google Earth (Google; accessed in August 2011) (Fig. 1A). Trees that appeared discolored on satellite images were visited and sampled if symptoms resembled BLS. For the 2011 survey year, samples were collected from 20 different tree species and the location of each tree was recorded (Table 1). 
In total, 64 sites with trees that tested ELISA positive for $X$. fastidiosa in 2011 were revisited for more extensive sampling in 2012 (15 August to 12 October). In addition to the 64 previously sampled sites, 31 new sites with trees displaying symptoms of leaf scorch were sampled. Additional sites were selected when symptomatic trees were observed during field collection. Sampling in 2012 included (i) symptomatic and asymptomatic foliage of trees determined to be infected in 2011, (ii) symptomatic and asymptomatic foliage of neighboring symptomatic trees, and (iii) foliage from asymptomatic neighboring trees. Neighboring trees were selected within a $25-\mathrm{m}$ radius of an infected tree and were gener- ally located within 5 to $10 \mathrm{~m}$. In total, 95 sampling sites comprising over 340 urban trees were sampled throughout the District during the 2012 survey.

Sampling on symptomatic trees included (i) 8 to 12 leaves from the most severely scorched portion of the canopy and (ii) 8 to 12 asymptomatic leaves from branches located as far as possible from the symptomatic portion of the canopy. If trees were entirely scorched and there was an absence of asymptomatic foliage, trees were sampled from the most scorched portion of the crown. On asymptomatic trees, two to three leaf samples were obtained from four opposing directions, resulting in a combined total of 8 to 12
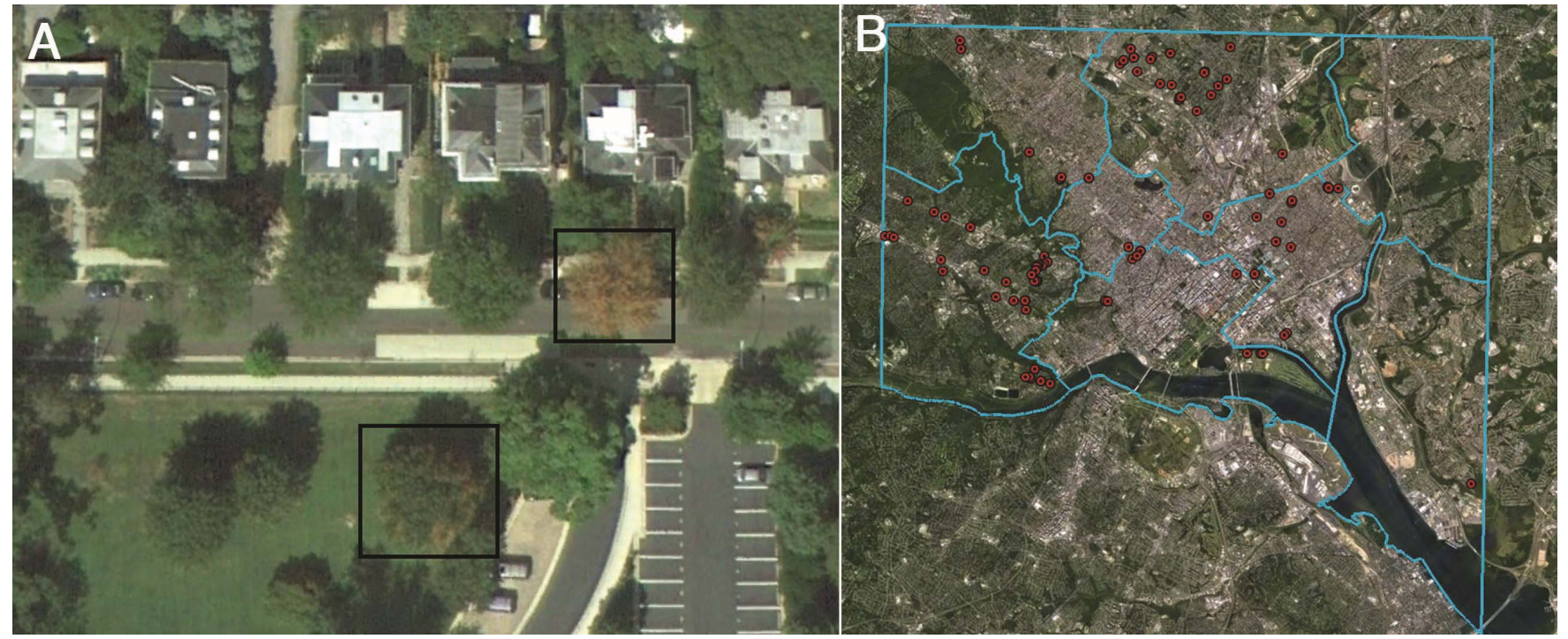

Fig. 1. A, Satellite image showing an oak tree with a discolored canopy that is selected for sampling and B, study sites with positive detection of Xylella fastidiosa in seven of the eight District wards.

Table 1. Number of Xylella fastidiosa-infected urban trees surveyed in the District of Columbia in 2011 and $2012^{a}$

\begin{tabular}{|c|c|c|c|c|}
\hline \multirow[b]{2}{*}{ Tree species } & \multicolumn{2}{|c|}{2011 Survey } & \multicolumn{2}{|c|}{2012 Survey } \\
\hline & $\begin{array}{l}\text { Symptomatic trees, } \\
\text { symptomatic foliage }\end{array}$ & $\begin{array}{l}\text { Asymptomatic trees, } \\
\text { asymptomatic foliage }\end{array}$ & $\begin{array}{l}\text { Symptomatic trees, } \\
\text { asymptomatic foliage }\end{array}$ & $\begin{array}{l}\text { Symptomatic trees, } \\
\text { symptomatic foliage }\end{array}$ \\
\hline Acer negundo & ns & ns & $0 / 1(0)$ & $0 / 1(0)$ \\
\hline A. platanoides & $1 / 3(33)$ & $0 / 3(0)$ & $0 / 6(0)$ & $0 / 7(0)$ \\
\hline A. rubrum & $0 / 6(0)$ & $0 / 7(0)$ & $0 / 5(0)$ & $0 / 9(0)$ \\
\hline Aesculus hippocastaneum & $0 / 4(0)$ & $\mathrm{ns}$ & ns & ns \\
\hline Catalpa speciosa & ns & ns & $0 / 1(0)$ & $0 / 1(0)$ \\
\hline Cladrastis kentukea & ns & ns & ns & $0 / 1(0)$ \\
\hline Cornus florida & ns & $0 / 1(0)$ & $\mathrm{ns}$ & $\mathrm{ns}$ \\
\hline Fraxinus pennsylvanica & $0 / 4(0)$ & ns & ns & $\mathrm{ns}$ \\
\hline Ginkgo biloba & $3 / 9(33)$ & $0 / 9(0)$ & $0 / 7(0)$ & $1 / 13(8)$ \\
\hline Liquidambar styraciflua & $1 / 1(100)$ & ns & ns & ns \\
\hline Liriodendron tulipifera & $1 / 2(50)$ & $\mathrm{ns}$ & $1 / 3(33)$ & $1 / 5(20)$ \\
\hline Magnolia sp. & $0 / 1(0)$ & ns & ns & ns \\
\hline Morus alba & $1 / 1(100)$ & $1 / 2(50)$ & $3 / 4(75)$ & $3 / 4(75)$ \\
\hline Platanus occidentalis & $12 / 18(67)$ & $0 / 12(0)$ & $4 / 14(29)$ & $10 / 15(67)$ \\
\hline Platanus $\times$ acerifolia & $\mathrm{ns}$ & $0 / 2(0)$ & $0 / 1(0)$ & $0 / 1(0)$ \\
\hline Quercus alba & ns & $0 / 1(0)$ & ns & ns \\
\hline Q. bicolor & $0 / 1(0)$ & ns & ns & ns \\
\hline Q. coccinea & $0 / 2(0)$ & $1 / 1(100)$ & $0 / 1(0)$ & $2 / 2(100)$ \\
\hline Q. macrocarpa & $3 / 5(60)$ & $0 / 2(0)$ & $0 / 2(0)$ & $1 / 2(50)$ \\
\hline Q. palustris & $18 / 19(95)$ & 7/37 (19) & $18 / 29(62)$ & $38 / 40(95)$ \\
\hline Q. phellos & $1 / 5(20)$ & $0 / 1(0)$ & $1 / 1(100)$ & $1 / 1(100)$ \\
\hline$Q$. prinus & $0 / 2(0)$ & ns & ns & ns \\
\hline Q. rubra & $36 / 48(75)$ & $7 / 60(12)$ & $29 / 52(56)$ & $57 / 61(93)$ \\
\hline Tilia americana & $0 / 1(0)$ & ns & $0 / 3(0)$ & $0 / 3(0)$ \\
\hline Ulmus americana & $19 / 35(54)$ & $6 / 21(29)$ & $12 / 18(67)$ & $16 / 20(80)$ \\
\hline Ulmus parvifolia & $0 / 2(0)$ & ns & ns & ns \\
\hline Sum & $96 / 169(57)$ & 22/159 (14) & $68 / 148(46)$ & $130 / 186(70)$ \\
\hline
\end{tabular}

a X. fastidiosa-specific double-antibody sandwich (DAS) enzyme-linked immunosorbent assay (ELISA) was used to detect the pathogen in leaves with symptoms resembling those of bacterial leaf scorch. In 2012, asymptomatic trees neighboring a symptomatic tree and, if present, asymptomatic foliage of symptomatic trees was also tested for X. fastidiosa. Values indicate the number of positive detection/total number of samples and (percent of detection); ns indicates that no samples were collected or present for this category. 
leaves. This procedure was performed as scrupulously as the branch architecture permitted; however, inability to access upper canopy foliage confined the leaf collection range to the lower $7 \mathrm{~m}$ of the canopy. For sample collection from high branches, a 6.4-m silky Hayauchi extension pole-saw (UM Kogyo, Inc.) was used. Branches that could be reached without the assistance of a polesaw were sampled with felco F-2 hand-pruners (Pygar USA Inc.). After collecting leaves, the petioles and midribs, where $X$. fastidiosa bacteria are found in the highest concentrations $(17,21)$, were harvested by cutting away excessive leaf tissue. All collection utensils (the pole-saw, the hand-pruners, and the scissors) were consistently surface disinfested with $70 \%$ ethanol between sample collections. The petioles and midribs of an individual sample were stored in a sterile $15-\mathrm{ml}$ test tube and transferred in a cooler to the lab the same day and frozen at $-20^{\circ} \mathrm{C}(29)$.

In 2012, samples were collected from 19 different species of urban trees (Table 1). Information regarding the site location and physical characteristics of each tree, including tree species, height, and stem diameter at breast height (DBH), was recorded. Each tree was assigned a rating based on the amount of crown dieback: $0=$ no tip dieback, minimal deadwood $<2.5 \mathrm{~cm}$ in diameter; $1=<25 \%$ dieback, dieback observed at tips of branches, deadwood generally $<5 \mathrm{~cm}$ in diameter; and, $2=\geq 25 \%$ dieback, reduction in crown size, deadwood $>5 \mathrm{~cm}$ in diameter, failure of entire limbs, and growth of epicormic sprouts. In addition, every tree was assigned a visually estimated leaf scorch percentage (0 to 100\%). This approximation represented the percentage of the tree crown that displayed leaf scorch.

Detection of $X$. fastidiosa using ELISA. The $X$. fastidiosa-specific, double-antibody sandwich (DAS)-ELISA (Agdia Inc.) was used in accordance with the manufacturer's protocol in 2011. In 2012 , instead of using the mesh bags provided by the manufacturer, the MP FastPrep-24 instrument was used for maceration to provide greater consistency when processing samples (MP Biomedicals). This step involved dissecting 8 to 12 leaf petioles into approximately $0.5-\mathrm{mm}$ pieces using a sterile razor blade and then placing $0.1 \mathrm{~g}$ of tissue into a $2-\mathrm{ml}$ lysing matrix A test tube (MP Biomedicals), with $1 \mathrm{ml}$ of general extraction buffer. Sample tubes were then processed twice for $40 \mathrm{~s}$ at a speed of $4.5 \mathrm{~m} / \mathrm{s}$ using the MP FastPrep-24 instrument. Each sample was assigned three test wells to ensure consistent ELISA readings, along with positive and negative controls for each plate.

In 2011, absorbance values were not measured and positive detection was determined based on color changes according to the manufacturer's protocol. In 2012, the optical absorbance values of all ELISA reactions were read at $650 \mathrm{~nm}$ using a Bio-Rad Benchmark microplate reader (Bio-Rad). A reaction was determined positive if the sample well had an absorbance value (absorbance unit) greater than the mean absorbance value of all negative control wells plus four times the standard deviation (48). In this study, a sample was deemed positive for $X$. fastidiosa when the ELISA absorbance values were $\geq 0.30 \quad(n=62$, negative control $=0.18 \pm$ 0.03 , and positive control $=1.76 \pm 0.30$ ).

DNA extraction and PCR analysis. Using samples collected in 2012, subsets consisting of no more than 10 samples for each ELISA-positive tree species were selected for analysis using a multiprimer PCR assay (18). Total DNA was extracted from ELISA-positive petiole samples using a DNeasy kit (Qiagen Inc.), according to the manufacturer's protocol, with the following modification. The maceration step in the protocol was carried out in 2$\mathrm{ml}$ lysing matrix tubes consisting of lysing matrix A, and samples were processed twice in a MP FastPrep-24 instrument for $40 \mathrm{~s}$ at a speed of $4.5 \mathrm{~m} / \mathrm{s}$.

A multiprimer PCR assay designed by Hernandez-Martinez et al. (18) was performed with the following modifications. For all reactions, $2 \mu \mathrm{l}$ of total DNA extract was added to $12.5 \mu \mathrm{l}$ of $2 \times$ GoTaq Green Master Mix (Promega Corporation); $0.25 \mu \mathrm{l}(100 \mu \mathrm{M}$ solution) of the primers XF2542-R (5'-CAGTACAGCCTGCTG GAGTTA-3'), XF2542-L (5'-TTGATCGAGCTGATGATCG-3'), XF1968-R (5'-ATCCACAGTAAAACCACATGC-3'), XF1968-L
(5'-GGAGGTTTACCGAAGACAGAT-3'), ALM1 (5'-CTGCAG AAATTGGAAACTTCAG-3'), and ALM2 (5'-GCCACACGTGAT CTATGAA-3') (Invitrogen); and $9 \mu \mathrm{l}$ of molecular-grade water for a total volume of $25 \mu \mathrm{l} /$ reaction (18). These three primer sets allow the differentiation of strains $X$. fastidiosa subsp. fastidiosa, X. fastidiosa subsp. sandyi, and X. fastidiosa subsp. multiplex, with distinction between the ALSI and ALSII genotypes within the multiplex subspecies. All amplifications were performed in a Bio-Rad S1000 Thermal Cycler (Bio-Rad), and carried out with the following cycle program: $5 \mathrm{~min}$ at $94^{\circ} \mathrm{C}$; followed by 39 cycles of $94^{\circ} \mathrm{C}$ for $1 \mathrm{~min}, 55^{\circ} \mathrm{C}$ for $1 \mathrm{~min}$, and $72^{\circ} \mathrm{C}$ for $1 \mathrm{~min}$; and a final extension step of $10 \mathrm{~min}$ at $72^{\circ} \mathrm{C}$. PCR products were run in a $1.5 \%$ agarose gel (Fisher Scientific) in $1 \times$ sodium boric acid conductive medium (5), and post-stained with GelRed (Biotium) at a 1:3,300 ratio of stock reagent to distilled water.

Statistical analyses. The association between crown dieback ratings and presence or absence of $X$. fastidiosa on four common amenity trees was evaluated using $\chi^{2}$ contingency tables and the significance of the difference identified using the likelihood ratio and Pearson test. A simple linear regression analysis was used to test ELISA values (independent variable) in relation to scorch percentage (dependent variable) of trees. ELISA values of asymptomatic and symptomatic foliage of infected trees among the four most frequently sampled tree species were compared and differences in variances of means were separated using one-way analysis of variance (ANOVA) an the significance level identified using an $F$ test. Transformation of ELISA values for ANOVA was not necessary because data were normally distributed. The statistical software JMP 10.0.2 (2012; SAS Institute Inc.) was used in all statistical analyses.

\section{Results}

Occurrence of BLS in the District. BLS was found in seven of the eight District wards delineated by the District Department of Transportation Urban Forestry Administration (Fig. 1B). Of the 95 testing sites, 88 possessed a leaf-scorched tree positive for $X$. fastidios $a$ and 47 contained more than one $X$. fastidiosa-infected tree. Red oak, pin oak, elm, and sycamore trees were the most common leaf-scorched trees found in the District based on satellite imagery and roadside observation (Table 1).

Leaf scorch symptoms developed late in August during both the 2011 and 2012 survey years. Symptoms displayed on infected trees were consistent with previously reported descriptions of BLS symptoms $(17,42)$ (Fig. 2A-D). Early leaf senescence was commonly noticed on BLS-affected pin oak, with symptoms appearing much earlier than in other tree species (Fig. 2E). X. fastidiosainfected red oak trees were observed with severe dieback and stunting (Fig. 2F).

In 2011,169 symptomatic trees belonging to 20 tree species were sampled and tested for X. fastidiosa (Table 1). Overall, 57\% (96 of 169) of trees with symptoms of BLS tested positive for $X$. fastidiosa using ELISA. The percentage of infected trees varied based on tree species and was highest for pin oak (Quercus palustris), followed by northern red oak (Q. rubra), American elm (Ulmus americana), and sycamore (Platanus occidentalis), all of which were the most frequently sampled tree species (Table 1).

The majority of revisited trees with a positive detection of $X$. fastidiosa in 2011 had a positive detection of X. fastidiosa in 2012 (Table 1). The exceptions occurred with one Norway maple (Acer platanoides), two ginkgo trees (Ginkgo biloba) within a single site, and one bur oak ( $Q$. macrocarpa). These trees tested positive for $X$. fastidiosa in 2011 and displayed BLS symptoms but failed to provide a positive ELISA result in 2012. In total, 27 additional sites (27 of 31) were found with at least one tree ELISA positive for $X$. fastidiosa. Of the 186 leaf-scorched trees examined in 2012, 70\% (130 of 186) were ELISA positive for X. fastidiosa (Table 1). Tree species within the red oak family and elm, white mulberry $(M$. alba), and sycamore with characteristic BLS symptoms generally tested positive for the detection of $X$. fastidiosa in ELISA. The greatest mean ELISA value was recorded with pin oak (Table 2). 
Tree species that displayed BLS symptoms but were consistently ELISA negative for $X$. fastidiosa in both 2011 and 2012 included red maple (A. rubrum) and American linden (Tilia americana). An ELISA-positive detection of $X$. fastidiosa was possible with single samples of ginkgo and Norway maple; however, all other symptomatic trees from these two tree species were ELISA negative. Other less extensively evaluated symptomatic species that were ELISA negative included horse chestnut (Aesculus hippocastanum), yellowwood (Cladrastis kentukea), green ash (Fraxinus pennsylvanica), London plane $(P . \times$ acerfolia $)$, flowering dogwood (Cornus florida), magnolia (Magnolia sp.), white oak ( $Q$. alba), swamp white oak ( $Q$. bicolor) chestnut oak ( $Q$. prinus), Chinese elm (U. parvifolia), boxelder (Acer negundo), and catalpa (Catalpa speciosa) (Table 1).

Detection of $X$. fastidiosa in the asymptomatic foliage of infected trees. When asymptomatic leaves from $X$. fastidiosa-infected trees were tested for latent infections of $X$. fastidiosa, trees in the red oak family, including pin oak, red oak, scarlet oak, and willow oak ( $Q$. phellos), had a high incidence of ELISA-detection, with over half of the samples yielding positive detection (Table 1). Similarly, 67\% (12 of 18) of asymptomatic samples derived from infected elm tested ELISA-positive. Asymptomatic leaves derived from an infected mulberry were generally ELISA positive $(75 \% ; 3$ of 4). When mean ELISA values of symptomatic and asymptomatic foliage from infected trees were compared for the four most frequently sampled tree species, symptomatic foliage always had a significantly greater mean ELISA value than the asymptomatic foliage (Table 2).

Detection of $X$. fastidiosa in asymptomatic trees. Fourteen asymptomatic tree species in close proximity to an $X$. fastidiosainfected tree were examined for $X$. fastidiosa. Of 159 entirely asymptomatic trees, $22(14 \%)$ trees were positive for $X$. fastidiosa in ELISA (Table 1). An ELISA-positive detection for $X$. fastidiosa was possible for pin oak, red oak, scarlet oak (Q. coccinea), mulberry, and elm, despite the absence of BLS symptoms (Table 1). In several instances, asymptomatic pin oak and elm trees tested
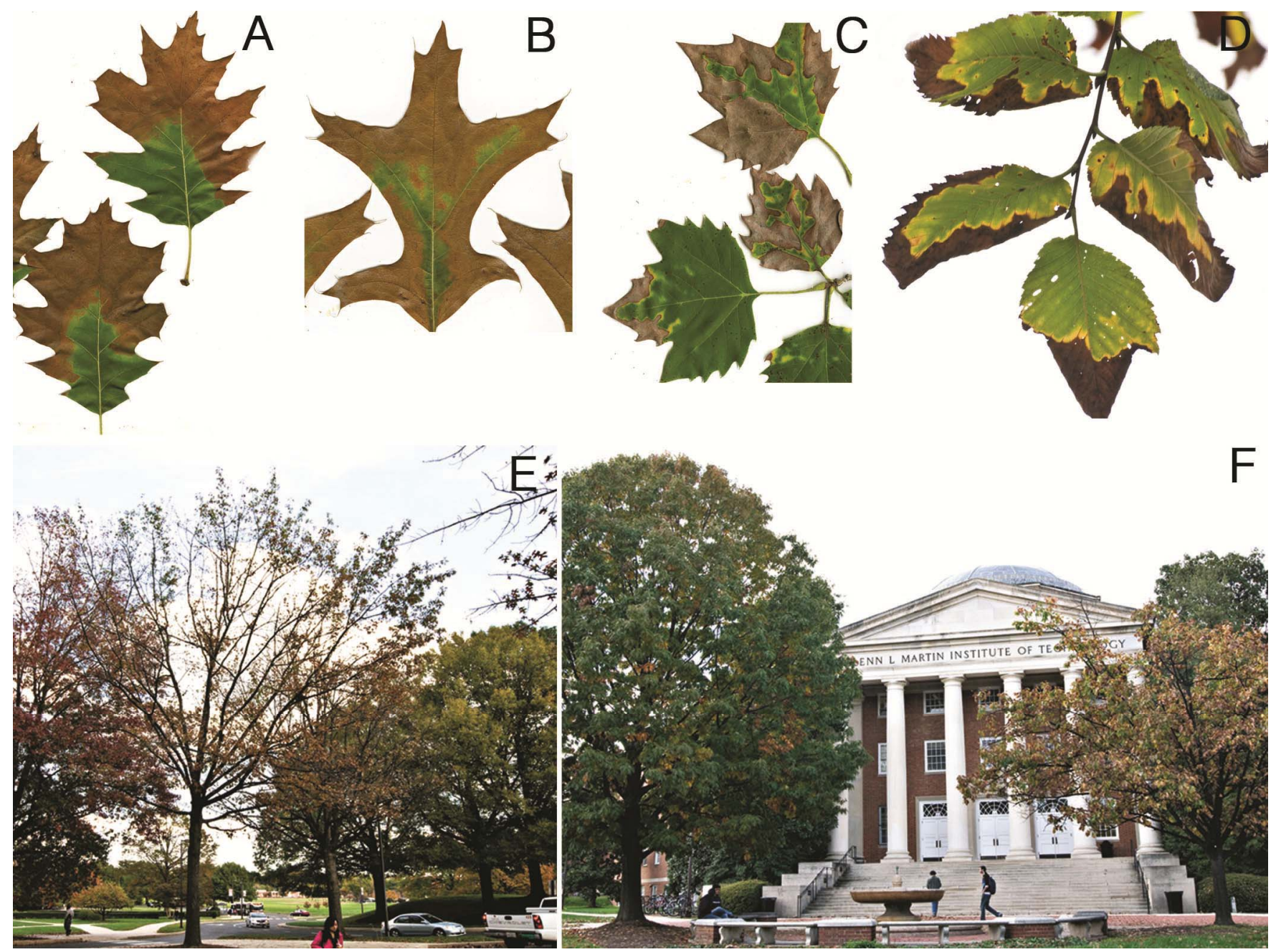

Fig. 2. Bacterial leaf scorch symptoms of amenity trees in the District of Columbia and in neighboring Maryland municipalities: Leaf scorch symptoms on A, red oak; B, pin oak; C, sycamore (Platanus occidentalis); and D, elm (Ulmus americana). Severe symptoms common with oaks: $\mathbf{E}$, early leaf drop on pin oak (Quercus palustris) and $\mathbf{F}$, stunting and chronic scorching on red oak (Q. rubra); tree on the right is infected.

Table 2. Analysis of variance of mean enzyme-linked immunosorbent assay values and standard deviation (Stdv) of asymptomatic and symptomatic foliage of Xylella fastidiosa-infected trees

\begin{tabular}{lrcccrr}
\hline Tree species & $\boldsymbol{n}$ & Asymptomatic foliage \pm Stdv & $\boldsymbol{n}$ & Symptomatic foliage \pm Stdv & \multicolumn{1}{c}{$\boldsymbol{F}$} & \multicolumn{1}{c}{$\boldsymbol{P}^{\mathbf{a}}$} \\
\hline Quercus palustris & 25 & $1.30 \pm 0.6$ & 38 & $1.75 \pm 0.3$ & 15.75 & $0.0002^{*}$ \\
Q. rubra & 36 & $1.10 \pm 0.5$ & 57 & $1.43 \pm 0.4$ & 15.05 & $0.0002^{*}$ \\
Platanus occidentalis & 4 & $0.89 \pm 0.5$ & 10 & $1.39 \pm 0.3$ & 4.92 & $0.0460^{*}$ \\
Ulmus americana & 18 & $0.56 \pm 0.3$ & 16 & $1.03 \pm 0.3$ & 21.22 & $<0.0001^{*}$ \\
\hline
\end{tabular}

a An asterisk (*) indicates significant differences at $P<0.05$. 
ELISA positive for $X$. fastidiosa and, although characteristic leaf scorch symptoms were absent, the trees displayed stunting of foliage, chlorosis, and epicormic sprouting on tree limbs.

PCR results and strain characterization. All ELISA-positive samples tested with PCR were positive, except for single samples of ginkgo and tulip poplar (data not shown). The resulting banding pattern for $X$. fastidiosa-positive elm, sycamore, red oak, and pin oak samples were consistent with the banding pattern for $X$. fastidiosa subsp. multiplex ALSII (Table 3). However, positive samples of mulberry resulted with banding patterns different than these tree species. Due to the low number of mulberry trees sampled, all ELISA-positive mulberry samples were tested, which included the asymptomatic samples from infected trees. Three mulberry trees displayed a single band indicating subsp. sandyi whereas two mulberry trees exhibited the banding pattern for subsp. multiplex ALSI and the subsp. sandyi (Table 3). On these two trees, there was no relation between symptom expression and subspecies present. On one mulberry tree, the symptomatic portion of the crown possessed the banding pattern for subsp. sandyi while the asymptomatic portion of the crown possessed the banding pattern for multiplex ASL1. On the second tree, this pattern was reciprocated; the symptomatic portion of the crown demonstrated the banding pattern for multiplex ALSI and the asymptomatic portion of the crown possessed the banding pattern for subsp. sandyi.

Association of ELISA values with DBH, tree height, crown dieback, and leaf scorching. There was a significant association between crown dieback and incidence of X. fastidiosa (Table 4). However, no association existed between the presence of $X$. fastidiosa and tree DBH or height for any species tested (data not shown). Scorch percentage was positively correlated for red and pin oak trees ( $F$ was significant at $P=<0.001$ for both species); however, this was not true for sycamore and elm trees ( $F$ was nonsignificant at $P=0.309$ and 0.059 , respectfully) (Fig. 3A-D).

\section{Discussion}

$X$. fastidiosa was detected in 12 urban tree species in the District. All these species have previously been reported as hosts, ex- cept for Norway maple and tulip poplar. Although we have not fulfilled Koch's postulates for the latter species, an ELISA-positive detection of $X$. fastidiosa suggests an association of $X$. fastidiosa with these tree species. Over the past 30 years, more than 40 species of landscape trees have been found to harbor $X$. fastidiosa $(24,42)$. Trees that are detrimentally affected by BLS include many species of oak $(1,12,17,22,23,26)$, elm $(25,41,50)$, sycamore $(3,16,22,43)$, and maple $(3,13,46)$. The impact of BLS in the District is prevalent on oak species, particularly pin and red oak, as is evident by the large amount of crown dieback observed in these two species. Other urban trees such as elm and sycamore were found with BLS but did not exhibit the crown dieback witnessed on red and pin oak trees. Various other oak species are adversely impacted by BLS in other metropolitan areas along the east coast. In New Jersey, incidences as high as $30 \%$ were noted for northern red oak, pin oak, and scarlet oak (30). Further south, an ELISAbased survey of trees found BLS occurring on symptomatic pin oak, red oak, shingle oak (Q. imbricaria) and white oak ( $Q$. alba) in 16 cities and towns in Kentucky (12). The study also detected BLS in scarlet oak, post oak (Q. stellata), water oak ( $Q$. nigra), swamp oak ( $Q$. bicolor), chestnut oak ( $Q$. prinus), and willow oak in most major metropolitan areas in Tennessee. Within the Carolinas, positive ELISA detection of $X$. fastidiosa was reported in pin oak and southern red oak (Q. falcata) (15). The association of BLS with oak decline in urban settings extends as far south as Florida and includes turkey oak (Q. laevis) and southern red oak (1).

In our study, the majority of asymptomatic trees neighboring $X$. fastidiosa-infected trees were free of the bacterium (137 of 159 trees). However, $X$. fastidiosa was still detected in several samples of red and pin oak, elm, and mulberry. Other studies have found similar results when symptomless oak and elm trees were tested in areas where $X$. fastidiosa was established $(1,6,17,44)$. Tree species including boxelder (A. negundo) and buckeye (Aesculus $\times$ hybrid) were previously reported with asymptomatic infection in the District (32). Similarly, in an investigation of the natural occurrence of $X$. fastidiosa in a Maryland nursery, crape myrtle (Lagerstroemia indica) within the nursery as well as sassafras (Sassafras albidum)

Table 3. Subspecies and strain genotypes of Xylella fastidiosa from environmental samples obtained from petioles of infected urban tree species

\begin{tabular}{lccccc}
\hline & & \multicolumn{3}{c}{ PCR assay fragments } & \\
\cline { 2 - 5 } Host species & $\boldsymbol{n}$ & XF1968 & ALM & XF2542 & Strain subspecies/genotype \\
\hline Morus alba & 5 & + & - & - & sandyi \\
M. alba & 2 & + & + & - & multiplex/ALSI \\
Platanus occidentalis & 10 & + & + & + & multiplex/ALSII \\
Quercus coccinea & 3 & + & + & + & multiplex/ALSII \\
Q. macrocarpa & 1 & + & + & + & multiplex/ALSII \\
Q. palustris & 10 & + & + & + & multiplex/ALSII \\
Q. phellos & 1 & + & + & multiplex/ALSII \\
Q. rubra & 10 & + & + & multiplex/ALSII \\
Ulmus americana & 10 & + & + & multiplex/ALSII \\
\hline
\end{tabular}

${ }^{a}$ Polymerase chain reaction (PCR) products were amplified using three primer sets (see Materials and Methods); + indicates DNA product was obtained and visually observed after gel electrophoresis, and - indicates DNA product was not obtained.

Table 4. Contingency table: Crown dieback of Xylella fastidiosa-infected and noninfected trees ${ }^{\mathrm{a}}$

\begin{tabular}{|c|c|c|c|c|c|c|c|}
\hline \multirow[b]{2}{*}{ Tree species } & \multirow[b]{2}{*}{ Status of $X$. fastidiosa } & \multicolumn{3}{|c|}{ Crown dieback $^{b}$} & \multirow[b]{2}{*}{ Test } & \multirow[b]{2}{*}{$\chi^{2}$} & \multirow[b]{2}{*}{$P>\chi^{2}$} \\
\hline & & $\mathbf{0}$ & 1 & 2 & & & \\
\hline \multirow[t]{2}{*}{ Quercus palustris } & Absent & 24 & 12 & 6 & Likelihood ratio & 36.41 & $<0.0001$ \\
\hline & Present & 6 & 16 & 40 & Pearson & 33.91 & $<0.0001$ \\
\hline \multirow[t]{2}{*}{ Q. rubra } & Absent & 48 & 20 & 12 & Likelihood ratio & 38.48 & $<0.0001$ \\
\hline & Present & 15 & 39 & 39 & Pearson & 36.93 & $<0.0001$ \\
\hline \multirow[t]{2}{*}{ Platanus occidentalis } & Absent & 16 & 5 & 6 & Likelihood ratio & 14.587 & 0.0007 \\
\hline & Present & 1 & 2 & 11 & Pearson & 13.196 & 0.0014 \\
\hline \multirow[t]{2}{*}{ Ulmus americana } & Absent & 12 & 10 & 3 & Likelihood ratio & 13.026 & 0.0015 \\
\hline & Present & 3 & 19 & 12 & Pearson & 12.511 & 0.0019 \\
\hline
\end{tabular}

a Infected trees were determined with enzyme-linked immunosorbent assay.

${ }^{\mathrm{b}}$ Crown dieback rating: $0=$ no tip dieback (minimal deadwood $<2.5 \mathrm{~cm}$ in diameter), $1=<25 \%$ dieback (dieback observed at tips of branches, deadwood generally $<5 \mathrm{~cm}$ in diameter), and $2=\geq 25 \%$ dieback (reduction in crown size, deadwood $>5 \mathrm{~cm}$ in diameter as well as failure of entire limbs, epicormic sprouting). 
and mimosa (Albizia julibrissin) trees bordering the nursery were found to harbor $X$. fastidiosa without expressing leaf scorch symptoms (24). The reason for inconsistent development of symptoms among various tree species after $X$. fastidiosa infection remains unresolved.

Approximately half of our study sites possessed more than one infected tree. It is not clear why disease incidence is limited to individual trees at certain sites, or the rate at which $X$. fastidiosa is disseminated among susceptible neighboring trees. The spread of BLS is primarily attributed to xylem-feeding insect vectors, including a wide range of treehoppers (Membracidae) and leafhoppers (Cicadellidae), which are found abundantly in urban environments $(2,52)$. The amount of vector feeding required before a tree becomes infected is unknown, and the inoculation pressure sufficient to cause infection in some plants may differ from other plants (17). If each tree species has a different vector inoculation pressure threshold required for infection, the amount of inoculum available to insect vectors within the area may play a significant role in determining which trees become infected. Consequently, understanding which tree species are source plants for vector acquisition of $X$. fastidiosa is an important consideration when assessing management options for a particular infection site (51).

For the majority of samples, ELISA results corresponded with PCR results when testing for $X$. fastidiosa. However, discrepancies in detection of $X$. fastidiosa occurred for ginkgo and tulip poplar. Each species tested positive for $X$. fastidiosa with ELISA but not in PCR. Failure to detect $X$. fastidiosa with PCR may be due to the inability to remove plant-originating inhibitory compounds during the DNA extraction process. For example, with tulip poplar, the lysing product after the maceration step was extremely viscid and the resulting supernatant required additional extraction buffer in order to permeate the DNA-binding membrane during DNA extraction; therefore, the success of DNA extraction with this anomaly is questionable. In other studies, inhibitory compounds originating from plant or insect tissue were suspected not to be entirely removed during DNA extraction, resulting in an inability to amplify DNA using nested PCR $(32,37)$. This dilemma was partially solved using immunomagnetic separation to isolate bacteria from insect vectors; however, the use of this technique to separate DNA from plant hosts proved unsuccessful $(32,37)$.

The subsp. multiplex was associated with BLS on elm, pin oak, red oak, scarlet oak, bur oak, and sycamore in the District. This subspecies was previously reported to be responsible for disease of woody perennial hosts, including the ones found in this study $(33,35,39,40)$. However, subsp. multiplex genotype ALSI and subsp. sandyi were found associated with mulberry leaf scorch. The subspecies responsible for disease of mulberry has not yet been described (19) and, although our PCR assay was instrumental in determining the genetic variability of the strains found among urban trees, additional molecular analysis is required before assigning the strains found in mulberry to a definitive subspecies. If the strains identified in mulberry are not responsible for disease of amenity trees, then an eradication effort aimed at reducing uncultivated mulberry would not be effective at reducing $X$. fastidiosa infection among amenity trees. Another limitation of the in vivo PCR assay used in our investigation is the inability of accounting for multiple subspecies within the same plant sample. Similar to two mulberry trees in this study, cohabitation of genetically varia-
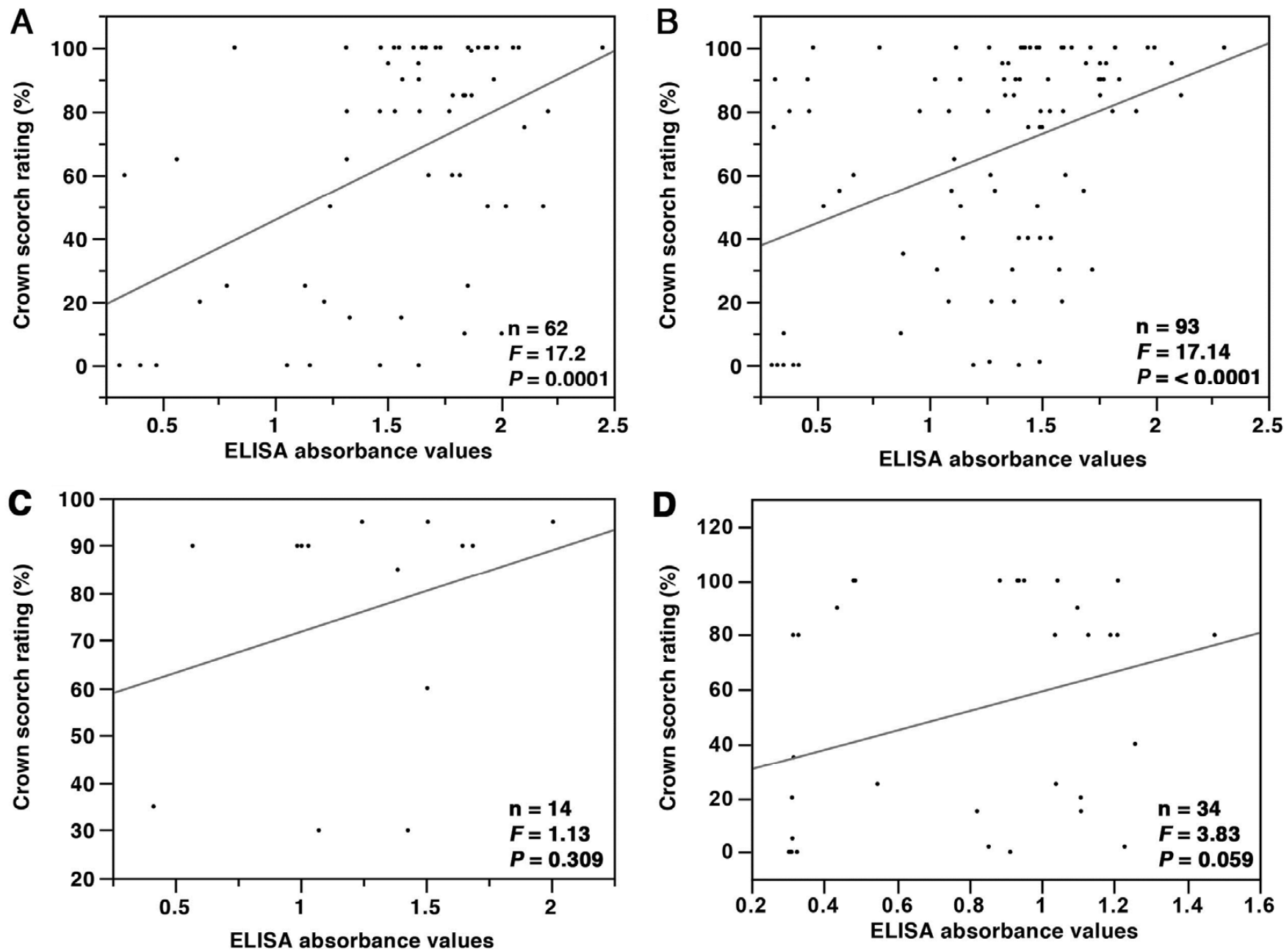

Fig. 3. Logistic fit of enzyme-linked immunosorbent assay (ELISA) values in correlation with scorch rating on the most commonly sampled urban trees infected with Xylella fastidiosa. A, Quercus palustris; B, Q. rubra; C, Platanus occidentalis; and D, Ulmus americana. 
ble strains of $X$. fastidiosa has been observed in almond trees (7). If such a cohabitation is occurring in landscape trees, alternative methods must be employed to further characterize the $X$. fastidiosa strains within the District. A probe-based real-time PCR method for multilocus melt typing of $X$. fastidiosa strains in plant samples was suggested to resolve any genotypic diversity without the need for culturing (4).

This study did not attempt to quantify the population of $X$. fastidiosa within each host; however, significant differences in ELISA values were noted among various tree species, as well as among symptomatic and asymptomatic plant tissue. In a previous study, larger ELISA optical absorbance values were found indicative of larger X. fastidiosa concentrations within grapevine (Vitis spp.) (29). If greater ELISA values are indicative of a larger bacterial population, our data suggest that a larger bacterial population is correlated with severe leaf scorch and crown dieback for red and pin oak. If accurate, this suggests that oak may be a good candidate host plant for $X$. fastidiosa acquisition from insect vectors. Realtime PCR (36) could validate the association between bacterial concentration, symptom severity, and tree species, and ELISA may prove to be a very useful method for quantifying pathogen population.

ELISA values of asymptomatic foliage of infected trees provided new insight regarding the etiology of $X$. fastidiosa within the canopy. The bacterium was commonly detected within asymptomatic foliage of infected red oak, pin oak, and elm, with over half of the samples testing positive in ELISA. Similarly, the bacterium was found in about $50 \%$ of tracheary elements taken from symptomless branches of diseased elm trees using electron microscopy (17). The significantly lower ELISA values of asymptomatic foliage compared with the symptomatic foliage suggest that larger bacterial titer is required before symptoms become apparent. On this note, we considerably lack knowledge of (i) whether systemic movement or repeated inoculation by vectors is the primary mechanism of $X$. fastidiosa dissemination within the crown of a tree and (ii) the duration of latent infection prior to the onset of symptoms.

An economical management option for BLS such as pruning infected branches to eliminate or reduce the spread of $X$. fastidiosa has not been experimentally demonstrated. Although the presence of $X$. fastidiosa in asymptomatic branches is indicative that pruning branches will not always eliminate $X$. fastidiosa from a tree, it could reduce the amount of inoculum available to vectors. Effective acquisition of $X$. fastidios $a$ by a vector was shown to require a large bacterial population within host tissue (20); thus, removal of infected tree branches that possess a larger bacterial population may reduce the rate at which vectors acquire the bacterium. In this regard, pruning might still be a useful management option for reducing the spread of the bacterium in urban ecosystems.

The 2010 Forest Action Plan for the District developed in accordance with the National Association of State Foresters and the U.S. Forest Service included BLS as an urban forest disease of concern. This study illustrates the regional extent of BLS in an urban environment. The four most commonly infected trees in this study were red oak, pin oak, elm, and sycamore. These four tree species represent $4.9 \%$ of urban trees and $19.7 \%$ of the total canopy coverage in the District (34). When infected with $X$. fastidiosa, these trees were found with a significantly greater incidence of crown dieback. Although BLS has been known to affect landscape ornamentals in the District for over 50 years (50), less is known about how climate change may influence the epidemiology of this disease in the coming years. Abiotic conditions such as water stress were shown to exacerbate BLS disease severity (31), and the chronic nature of $X$. fastidiosa infection may become increasingly acute if environmental conditions become optimal for vector activity (47) and bacterial propagation in host woody ornamentals (9).

\section{Acknowledgments}

Financial support for this research was provided by the District Department of Transportation, Urban Forestry Administration (DDOT UFA) through funds provided by the United States Department of Agriculture (USDA) Forest Ser- vice, Northeastern Area Cooperative Forest Health Program. We thank J. Perez and the DDOT UFA urban foresters for the assistance they provided in sample collection; A. Iskra, R. Turcotte, and D. Martin for their suggestions in developing the study and conducting the ELISA analysis in 2011; Q. Huang, M. Stulberg, and W. Guan for technical assistance with ELISA and PCR performed at the USDA Agricultural Research Service Beltsville laboratory; and J. Sherald for providing a critical review of this article.

\section{Literature Cited}

1. Barnard, E. L., Ash, E. C., Hopkins, D. L., and McGovern, R. J. 1998. Distribution of Xylella fastidiosa in oaks in Florida and its association with growth decline in Quercus laevis. Plant Dis. 82:569-572.

2. Bentz, J., and Sherald, J. 2001. Transmission of the xylem-limited bacterium Xylella fastidiosa to shade trees by insect vectors. Pages 203-208 in: Shade tree wilt diseases. C. L. Ash, ed. American Phytopathological Society, St. Paul, MN.

3. Blake, J. H. 1993. Distribution of Xylella fastidiosa in oak, maple, and sycamore in South Carolina. Plant Dis. 77:1262-1262.

4. Brady, J. A., Faske, J. B., Ator, R. A., Castaneda-Gill, J. M., and Mitchell, F. L. 2012. Probe-based real-time PCR method for multilocus melt typing of Xylella fastidiosa strains. J. Microbiol. Methods 89:12-17.

5. Brody, J. R., and Kern, S. E. 2004. Sodium boric acid: A Tris-free, cooler conductive medium for DNA electrophoresis. Biotechniques 36:214-216.

6. Chang, C. J., and Walker, J. T. 1988. Bacterial leaf scorch of northern red oak: Isolation, cultivation, and pathogenicity of a xylem-limited bacterium Plant Dis. 72:730-733.

7. Chen, J., Groves, R., Civerolo, E. L., Viveros, A., Freeman, A., and Zheng, Y. 2005. Two Xylella fastidiosa genotypes associated with almond leaf scorch disease on the same location in California. Phytopathology 95:708714.

8. DeStefano, D. A., Grybauskas, A. P., Sherald, J. L., Momen, B., Huang, Q., and Sullivan, J. H. 2007. Effect of the growth regulator paclobutrazol on growth of the bacterial pathogen Xylella fastidiosa. Arboricult. Urban For. 33:246-252.

9. Feil, H., and Purcell, A. H. 2001. Temperature-dependent growth and survival of Xylella fastidiosa in vitro and in potted grapevines. Plant Dis. 85:1230-1234.

10. Gould, A. B., Hamilton, G., Vodak, M., Grabosky, J., and Lashomb, J. 2004 Bacterial leaf scorch of oak in New Jersey: Incidence and economic impact. (Abstr.) Phytopathology 94:S36.

11. Hartman, J., Dixon, E., and Bernick, S. 2010. Evaluation of therapeutic treatments to manage oak bacterial leaf scorch. Arboricult. Urban For 36:140-146.

12. Hartman, J. R., Eshenaur, B. C., and Jarlfors, U. E. 1995. Bacterial leaf scorch caused by Xylella fastidiosa: A Kentucky survey: a unique pathogen; and bur oak, a new host. J. Arboricult. 21:77-82.

13. Hartman, J. R., Jarlfors, U. E., Fountain, W. M., and Thomas, R. 1996. First report of bacterial leaf scorch caused by Xylella fastidiosa on sugar maple and sweetgum. Plant Dis. 80:1302-1302.

14. Hartman, J. R., Kaiser, C. A., Jarlfors, U. E., Eshenaur, B. C., Bachi, P. R., and Dunwell, W. C. 1991. Occurrence of oak bacterial leaf scorch caused by Xylella fastidiosa in Kentucky. Plant Dis. 75:862-862.

15. Haygood, R. A., Jones, R. K., and Huang, P. Y. 1988. Fastidious, xyleminhabiting bacteria associated with scorch of pin oak and southern red oak trees in the Carolinas. (Abstr.) Phytopathology 78:628.

16. Haygood, R. A., Witcher, W., and Jones, R. K. 1988. Outbreak of sycamore leaf scorch in the Carolinas. Plant Dis. 72:644-644.

17. Hearon, S. S., Sherald, J. L., and Kostka, S. J. 1980. Association of xylemlimited bacteria with elm, sycamore, and oak leaf scorch. Can. J. Bot. 58:1986-1993.

18. Hernandez-Martinez, R., Costa, H. S., Dumenyo, C. K., and Cooksey, D. A. 2006. Differentiation of strains of Xylella fastidiosa infecting grape, almonds, and oleander using a multiprimer PCR assay. Plant Dis. 90:13821388 .

19. Hernandez-Martinez, R., de la Cerda, K. A., Costa, H. S., Cooksey, D. A. and Wong, F. P. 2007. Phylogenetic relationships of Xylella fastidiosa strains isolated from landscape ornamentals in southern California. Phytopathology 97:857-864.

20. Hill, B. L., and Purcell, A. H. 1997. Populations of Xylella fastidiosa in plants required for transmission by an efficient vector. Phytopathology 87:1197-1201.

21. Hopkins, D. L. 1981. Seasonal concentration of the Pierce's disease bacterium in grapevine stems, petioles, and leaf veins. Phytopathology 71:415418.

22. Hopkins, D. L., and Adlerz, W. C. 1988. Natural hosts of Xylella fastidiosa in Florida. Plant Dis. 72:429-431.

23. Huang, Q. 2004. First report of Xylella fastidiosa associated with leaf scorch in black oak in Washington, DC. Plant Dis. 88:224-224.

24. Huang, Q. 2007. Natural occurrence of Xylella fastidiosa in a commercial nursery in Maryland. Can. J. Plant Pathol. 29:299-303.

25. Kostka, S. J., Sherald, J. L., and Tattar, T. A. 1982. Isolation of bacteria from three elm species and mulberry exhibiting leaf scorch. Phytopathology 72:936-936. 
26. Kostka, S. J., Sherald, J. L., and Tattar, T. A. 1984. Culture of fastidious, xylem-limited bacteria from declining oaks in the northeastern states. Phytopathology 74:803-803.

27. Kostka, S. J., Tattar, T. A., and Sherald, J. L. 1985. Suppression of bacterial leaf scorch symptoms in American elm through oxytetracycline microinjection. Arboricult. Urban For. 11:54-58.

28. Kostka, S. J., Tattar, T. A., Sherald, J. L., and Hurtt, S. S. 1986. Mulberry leaf scorch, new disease caused by a fastidious, xylem-inhabiting bacterium. Plant Dis. 70:690-693.

29. Krivanek, A. F., and Walker, M. A. 2005. Vitis resistance to Pierce's disease is characterized by differential Xylella fastidiosa populations in stems and leaves. Phytopathology 95:44-52.

30. Lashomb, J., Gould, A. G., Iskra, M. S., and Hamilton, G. 2002. Bacterial leaf scorch of amenity trees: A wide-spread problem of economic significance to the urban forest. United States Department of Agriculture Forest Service Symposium for Review of Bacterial Leaf Scorch. U.S. Dep. Agric. For. Serv. Pub. No. NA-TP-01-03, p. 20.

31. McElrone, A. J., Sherald, J. L., and Forseth, I. N. 2001. Effects of water stress on symptomatology and growth of Parthenocissus quinquefolia infected by Xylella fastidiosa. Plant Dis. 85:1160-1164.

32. McElrone, A. J., Sherald, J. L., and Pooler, M. R. 1999. Identification of alternative hosts of Xylella fastidiosa in the Washington, D.C., area using nested polymerase chain reaction (PCR). J. Arboricult. 25:258-263.

33. Melanson, R. A., Sanderlin, R. S., McTaggart, A. R., and Ham, J. H. 2012. A systematic study reveals that Xylella fastidiosa strains from pecan are part of X. fastidiosa subsp. multiplex. Plant Dis. 96:1123-1134.

34. Nowak, D. J., Hoehn, R. E., III, Crane, D. E., Stevens, J. C., and Walton, J. T. 2006. Pages 17-20 in: Washington, D.C.'s Urban Forest. Northern Research Station, Newton Square, PA.

35. Nunney, L., Vickerman, D. B., Bromley, R. E., Russell, S. A., Hartman, J. R., Morano, L. D., and Stouthamer, R. 2013. Recent evolutionary radiation and host plant specialization in the Xylella fastidiosa subspecies native to the United States. Appl. Environ. Microbiol. 79:2189-2200.

36. Oliveira, A. C., Vallim, M. A., Semighini, C. P., Araujo, W. L., Goldman, G. H., and Machado, M. A. 2002. Quantification of Xylella fastidiosa from citrus trees by real-time polymerase chain reaction assay. Phytopathology 92:1048-1054.

37. Pooler, M. R., Myung, I. S., Bentz, J., Sherald, J., and Hartung, J. S. 1997. Detection of Xylella fastidiosa in potential insect vectors by immunomagnetic separation and nested polymerase chain reaction. Lett. Appl. Microbiol. 25:123-126

38. Randall, J. J., Goldberg, N. P., Kemp, J. D., Radionenko, M., French, J. M., Olsen, M. W., and Hanson, S. F. 2009. Genetic analysis of a novel Xylella fastidiosa subspecies found in the southwestern United States. Appl. Envi- ron. Microbiol. 75:5631-5638.

39. Schaad, N. W., Postnikova, E., Lacy, G., Fatmi, M. B., and Chang, C. J. 2004. Xylella fastidiosa subspecies: X. fastidiosa subsp. piercei, subsp. nov., $X$. fastidiosa subsp. multiplex subsp. nov., and $X$. fastidiosa subsp. pauca subsp. nov. Syst. Appl. Microbiol. 27:290-300.

40. Schuenzel, E. L., Scally, M., Stouthamer, R., and Nunney, L. 2005. A multigene phylogenetic study of clonal diversity and divergence in North American strains of the plant pathogen Xylella fastidiosa. Appl. Environ. Microbiol. 71:3832-3839.

41. Sherald, J. L. 1993. Pathogenicity of Xylella fastidiosa in American elm and failure of reciprocal transmission between strains from elm and sycamore. Plant Dis. 77:190-193.

42. Sherald, J. L. 2007. Bacterial leaf scorch of landscape trees: What we know and what we do not know. Arboricult. Urban For. 33:376-385.

43. Sherald, J. L., Hearon, S. S., Kostka, S. J., and Morgan, D. L. 1983. Sycamore leaf scorch: Culture and pathogenicity of fastidious xylem-limited bacteria from scorch-affected trees. Plant Dis. 67:849-852.

44. Sherald, J. L., and Lei, J. D. 1991. Evaluation of a rapid ELISA test kit for detection of Xylella fastidiosa in landscape trees. Plant Dis. 75:200-203.

45. Sherald, J. L., Patton, E. N., Stidham, T. M., and Favre, C. L. 1994. Incidence and development of bacterial leaf scorch of elm on the National Mall. J. Arboricult. 20:18-23.

46. Sherald, J. L. Wells, J. M., and Hurtt, S. S. 1987. Association of fastidious, xylem-inhabiting bacteria with leaf scorch in red maple. Plant Dis. 71:930933.

47. Son, Y., Backus, E. A., Groves, R. L., and Johnson, M. W. 2012. Pattern of stylet penetration activity by Homalodisca vitripennis (Hemiptera: Cicadellidae) adults in relation to environmental temperature and light conditions. Environ. Entomol. 41:1215-1230.

48. Sutula, C. L., Gillett, J. M., Morrissey, S. M., and Ramsdell, D. C. 1986 Interpreting ELISA data and establishing the positive-negative threshold. Plant Dis. 70:722-726.

49. Wells, J. M., Raju, B. C., Hung, H. Y., Weisburg, W. G., Mandelcopaul, L., and Brenner, D. J. 1987. Xylella fastidiosa gen. nov., sp. nov.: Gram-negative, xylem-limited, fastidious plant bacteria related to Xanthomonas spp. Int. J. Syst. Bacteriol. 37:136-143.

50. Wester, H. V., and Jylkka, E. W. 1959. Elm Scorch, graft transmissible virus of American elm. Plant Dis. Rep. 43:519.

51. Wistrom, C., and Purcell, A. H. 2005. The fate of Xylella fastidiosa in vineyard weeds and other alternate hosts in California. Plant Dis. 89:994999.

52. Zhang, J. X., Lashomb, J., Gould, A., and Hamilton, G. 2011. Cicadomorpha insects associated with bacterial leaf scorch infected oak in central New Jersey. Environ. Entomol. 40:1131-1143. 